\title{
Ahlâkî Tekâmülde Mûsikînin Rolü: Kindî’nin Mûsikî Risâleleri
}

\author{
The Role of Music in Moral Perfection: Musical Pamphlets of al-Kindî
}

\author{
Asiye Aykit ${ }^{1} \odot$
}

Öz

Arap mûsikîsi ilmî ekolünün kurucusu kabul edilen Kindî, Pythagoras ve Platon etkisiyle müzikal seslerle sayılar ve gök cisimleri arasında bağ kurar. Kindî’nin düşünce sisteminde mûsikî eğitimi ahlâkî kemâle ulaşmak ve bireysel olarak "ahenk" $i$ ve "itidal”i yakalayabilmek için oldukça mühimdir. Zira "ilmu’t-te'lif" olarak nitelenen mûsikî ilmi evrendeki ahenk ve düzenin bir yansımasıdır. Mûsikî nağmelerini icrâ eden ya da dinleyen kişi bu ahenge tabiî olarak iştirak eder. Buradan hareketle Kindî, mûsikînin insana etkisini, gök cisimlerinin insanın fizik ve metafizik tabiatına olan tesiri üzerinden açıklar. Enstrümanların tellerini gökcisimleri ile irtibatlandırır. Aynı şekilde tellerin çıkardığı bu melodilerin insan nefsinin algı kuvvelerine olan etkisini izah eder. Bu etki, idrak sürecinde huyların oluşumuna, erdemler ya da erdemsizliklerin meydana gelmesine tesir eder. Mûsikî aynı zamanda insana metafizik alemleri hatırlatmaktadır. Böylece insanın yönünü nefsinin asıl vatanı olan yüce âlemlere döndürerek tecrid etmesini ve ahlâkî kemâle ulaşmasını sağlar.

\section{Anahtar Kelimeler}

İslam Felsefesi, İslam Ahlak Felsefesi, Kindî, Ahlâk, Mûsikî, Nefis, Erdem

\begin{abstract}
Al-Kindi, who is considered the founder of the Arabic music school, establishes a connection between numbers and celestial objects with musical sounds under the influence of Pythagoras and Plato. In al-Kindi's thought system, the musical education is very important in order to reach moral virtue and to capture "harmony" and "sobriety" individually, since "ilmu't-te'lif", that is music, is a reflection of the harmony and order in the universe. The person who performs or listens to the musical tunes naturally participates in this harmony. Thus, Al-Kindi explains the influence of music on human beings through the influence of celestial bodies on the physical and metaphysical nature of human beings. He connects the strings of the instruments with celestial objects. In the same way, he explains the effect of these melodies produced by wires on the perception forces of the human soul. This effect affects the formation of temperament, emergence of virtues or lack of virtues in the process of perception. Music also reminds people of the metaphysical realms. Thus, it turns the direction of the human being into isolation, and reveals the moral virtue by turning the soul into its real world.
\end{abstract}

\section{Keywords}

Islamic Philosophy, Islamic Moral Philosophy, Al-Kindi, Morality, Music, Nafs, Virtue

1 Sorumlu Yazar: Asiye Aykıt (Dr. Öğr. Üyesi), Cumhuriyet Üniversitesi, İlahiyat Fakültesi, İslam Felsefesi Anabilim Dalı, Sivas, Türkiye. E-posta: asiye_sen@yahoo.com ORCID: 0000-0001-9142-9184 


\section{Extended Summary}

It is accepted that the entire existence is in harmony and order according to Islamic thought. This order, harmony, and rhythm in the universe as a matter of course created music. In our study, we dealt with the issue of music in terms of the effect of moral evolution. We examined the issue in the center of the Musical Pamphlets of Abu Ya'qūb ibn 'Ishāa al-Kindī (d. 866) who first discussed the issue of music among Islamic philosophers. A direct relationship has been established between thought of music and the idea of reaching moral isolation and perfection in al-Kindī's thought system. His thought of music has been the subject of many studies in terms of music theory. On the other hand, there is no systematic study on the effect of this knowledge on the physical and metaphysical structures of man, and their role in obtaining moral virtues. For this reason, in our study, we focus on the relationship that was established between the music and moral science in al-Kindī s Pamphlets.

Al-Kindi can be described as the owner of the first music school in the Islamic world. This school developed in the hands of al- Fārābī's, and reached its peak with Avicenna. With the effect of Pythagoras, al-Kindī made a connection between musical sounds and numbers and celestial substances. His method was particularly influential on Ikhwān alȘafā. In order to follow this effect, we compared al-Kindī s music views with the music ideas of Ikhwān al-Șafā. In our study, we examined the effects of music on moral evolution under three headings: In the first part, the relationship of music with heavenly bodies as a theory of harmony; in the second part, the effect of music on human nature through human temperament; in the last chapter, we discussed the effect of moral perfection on the effect of emergence of virtues.

Musical education in al-Kind̄' 's thought system is very important in terms of reaching moral belief, in order to attain "harmony" and "sobriety" individually, since the music that is described as "ilmu 't-te' 'lif" is a reflection of the harmony and order in the universe. The person who performs or listens to music is naturally involved in this harmony. Al-Kindī, who adopts the Pythagorean understanding of music from this perspective, explains the effect of music on humans within the framework of the influence of heavenly bodies on the physical and metaphysical nature of humans.

The movements of heavenly bodies affect the formation of all beings, especially human beings in the sub-universe. All assets in the sub-universe consist of four elements. These beings move from simple to compound and reach for perfection. Similarly, human beings try to reach perfection both physically and metaphysically. At this point, music is effective both in terms of the physical and metaphysical perfection of humans. Music affects his/ her temperament by influencing the proportion of liquids in the human body. This change in temperament changes moods and, accordingly, morality. In this way, music affects moral perfection through the physical structure of humans. Thus, musical melodies, 
which come together on a proportional harmony like in celestial bodies, positively affect human behavior. This leads to the formation of moral virtues. The voices without this proportional harmony, on the contrary, remind us of the lack of virtue. For this reason, the music that provides the moral competence of human beings should also be compatible with divine laws. Therefore, al-Kindī 's effort to explain the celestial origins of music also aims to give it legitimacy.

The effect of music on the metaphysical structure of the human being is realized within the framework of al-Kindī's isolation and purification. The harmony that arises from the movements of the heavenly bodies in the upper-universe is connected with the musical tunes in the sub-universe. As a result, the person who listens to these tunes will remember the celestial beings and metaphysical realms, and be willing to live there. In this case, humans will move away from the influence of the material realm and turn to the metaphysical realms. This is how the isolation activity, which is the most basic way of reaching moral ethics, takes place.

Al-Kindī states that those who want to study philosophy should first learn arithmetic, astronomy, logic and the sciences of music which are all included in the Mathematical sciences. With the effect of Plato, he believes that the science of music plays an important role in developing the mental faculties of humans, and therefore, plays a very important role in education. Today, musical education is very effective in strengthening the mental faculties of children and young people. Many Islamic philosophers have works that are related to music. There are valuable studies about these in terms of music theory. However, studies on the ontological and epistemological background of the issue are needed. 


\section{Giriş}

İslam düşüncesinde mevcûdâtın tümüyle bir ahenk ve düzen içerisinde olduğu kabul edilmektedir. Evrendeki bu düzen, ahenk (armoni) ve ritim, tabiî olarak mûsikîyi meydana getirmiştir. Bu sebeple mûsikî ilmi, ilmu't-te'lif diye isimlendirilerek usul ilimleri içerisinde ele alınmıştır. İnsan dinlemek, rahatlamak, duygulanmak, şifâ bulmak gibi pek çok sâikle dinlediği mûsikî nağmelerinde, aslında evrendeki bu ahengi hissetmeye ve tefekkür etmeye çalışmaktadır. Bu bakış açısıyla ahlâkî kemâle ulaşmak noktasında mûsikî eğitimi, bireysel olarak "ahenk"i, buna bağlı olarak"itidal"i yakalayabilmek için oldukça mühimdir. Mûsikî aynı zamanda toplumsal olarak da medeniyetlerin kurucu unsurlarından olan sanatın önemli bir bölümünü teşkil ettiği için tarihî-kültürel yapının sonraki nesillere aktarımında da çok önemlidir. Bu çalışmamızda, mûsikî konusunu, ahlâkî tekâmüle tesiri itibariyle ele alacağız. Meseleyi, İslam filozofları içerisinde mûsikî konusunu ilk olarak ele alan Ebû Yâ'kub b. İshak el-Kindî’nin (866) mûsikî risâleleri merkezinde inceleyeceğiz.

Kindî’nin düşünce sisteminde, mûsikî ilmiyle ahlâkî açıdan tecrîd ve kemâle ulaşma fikri arasında doğrudan bir ilişki kurulmuştur. Filozofun mûsikî düşüncesi, mûsikî nazariyâtı açısından incelenmiştir. ${ }^{1}$ Öte yandan bu ilmin insanın fizik ve metafizik yapısına etkisi, ahlâkî erdemleri elde etmedeki rolü konusunda sistematik bir çalışma bulunmamaktadır. Bu sebeple çalışmamızda, Kindî’nin Risâleleri’nin mûsikî düşüncesinin nazariyâtı hakkındaki ayrıntılı tahlillerinden ziyade, mûsikî ve ahlâk ilmi arasında kurmuş olduğu ilişkiye yoğunlaşılacaktır.

Kindî’nin yaşadığı Abbasîler döneminde, Emeviler'de ictimai hayatın vazgeçilmez bir unsuru olan mûsikînin ilmi yapısı işlenmeye başlamış ve İslam mûsikîsi nazariyâtı ve kaideleri ortaya konmaya çalışılmıştır. ${ }^{2}$ Başkent bir Akdeniz ülkesi olan Suriye'den, birçok ticaret yollarının kavşağı olan Irak'a geçmiş, böylece

1 Kindi'nin mûsikî nazariyatı hakkında ayrıntılı bilgi için bkz: Ahmet Hakkı Turabi, "EbûYa 'kūb b. İshâk el-Kindî’nin Müzik Risâlelerinde Tesbit Edilen Terimler," Marmara Üniversitesi Illahiyat Fakültesi Dergisi 25, no. 2 (2003): 65-78; Ahmet Hakkı Turabi, "el-Kindî’nin Mûsikî Risâleleri” (Yüksek Lisans Tezi, Marmara Üniversitesi, 1996); Hatice Toksöz, “Kindî’nin Düşünce Sisteminde Müzikal Seslerle Âlemdeki Düzen Arasındaki İlişkisi,” Diyanet İlmi Dergi 54, no. 2 (2018). Arap mûsikî nazariyesinin kaynağı, ilk dönem kullanılan enstrumanlar ve icralar hakkında ayrıntılı bilgi için bkz: Henry George Farmer, Tarihu'l-Musika 'l-Arabiyye, çev. H. Nassar (Kahire: 1956); O. Wright, The Modal System of Arab and Persian Music (London: 1978); Amnon Shiloah, Music in the World of Islam a Socio-Cultural Study (California: Wayne State University Press, 1995).

2 Ahmet Hakkı Turabi, "İlk Dönem İslâm Dünyasında Mûsikî Çalışmalarına Bakış,” Marmara Üniversitesi İlahiyat Fakültesi Dergisi 13-14-15, (1995-1997): 226, 240. 
Bizans yerine İran tesiri yoğunluk kazanmıştır. ${ }^{3}$ Bu tesir mûsikî sahasında da kendini göstermiştir. Bu dönemde tercüme edilen eserler mûsikînin de seyrini etkilemiştir.

Yunanlıların mûsikîye dair eserlerinin Beytü'l-Hikme'de Arapça'ya tercümesiyle birlikte Kindî, Grek coğrafyasındaki mûsikî nazarîyelerini Arabî zevke uygun bir şekilde mûsikîye tatbik etmiştir. Mûsikîşinaslar ve şarkıcılar için mûsikî melodileri ve formlarında kullanacakları nazarî kaideler koymuştur. Arap mûsikîsi ilmi ekolünün kurucusu kabul edilir. ${ }^{4}$ Matematik bilgisinden yoksun olanların kendi eserlerinin özüne vâkıf olamayacağını ifade eden Kindî’nin ortaya koyduğu esaslar, daha sonra Fârâbî, İbn Sînâ, Safiyyüddin el-Urmevî ve Abdülkâdir-i Merâgî için önemli hareket noktaları olmuştur. ${ }^{5}$

Kindî ve Fârâbî ile birlikte mûsikî ilmi "riyâzî ilimler" başlığı altında ilimler tasnifine dâhil edilmiştir. ${ }^{6}$ Kindî, eserlerinde müzisyenler ve şarkıcılar için müzik melodi ve formlarında kullanacakları teorik kuralları belirlemiştir. Dolayısıyla bu ilmin öğrencileri için kolay bir yol açmış ve ekol olmuştur. Kindî’yi İslâm dünyasında ilk müzik okulunun sahibi olarak niteleyecek olursak bu ekolün Fârâbî elinde gelişip İbn Sînâ'da zirvesini yaşadığını ifade edebiliriz. ${ }^{7}$ Pythagoras etkisiyle müzikal seslerle sayılar ve gök cisimleri arasında güçlü bağlar kuran Kindî’nin bu usulünün de özellikle İhvân-1 Safâ üzerinde etkili olduğunu ifade edebiliriz. Bu etkiyi takip edebilmek amacıyla çalışmamızda Kindî’nin mûsikî görüşlerini daha ziyade İhvân-1 Safâ'nın mûsikî fikirleriyle karşılaştırarak ele alacağız.

“Aristoteles' in Kitaplarının Sayımı Üzerine” isimli risâlesinde Kindî, mûsikî ilmini (ilmu't-te'lif); aritmetik, geometri, astronomi ile birlikte dört riyâzî ilimden biri saymaktadır. Bu ilimlerin hepsinde te'lif bulunduğunu, yani evrendeki düzen

3 Hakkı Dursun Yıldız, “Abbasîler,” Türkiye Diyanet Vakfi İslam Ansiklopedisi I, (1988): 33.

4 Turabi, “el-Kindî’nin Mûsikî Risâleleri,” 101.

5 Ahmet Hakkı Turabi, "Ya'kub b. İshak el-Kindî," Türkiye Diyanet Vakfi İslam Ansiklopedisi 26, (2002), 58-59.

6 Fârâbî’nin, Kindî’nin bu alandaki çalışmalarından da haberdar olduğu bilinmektedir. Daha sonra yazdığg eserlerde ve özellikle el-Mûsîka'l-kebîr'deYunanlılar'ın nazariyatını şerhetmekle kalmamış, iyi bir fizikçi ve matematikçi olduğu için Yunanlılar'dan eksik şekilde intikal eden nazariyat bilgilerini tamamlamış, hatta birçok noktada onların hatalarını düzeltmiştir. Bundan başka çalgılarla ilgili ayrıntılı incelemeler yapmış olması ve ses fiziğiyle ilgili çalışmalarında Yunanlılar'ı aşması ona mûsikî tarihinde müstesna bir yer kazandırmıştır. Bu hususta ayrıntılı bilgi için bkz: Alaeddin Jebrini, "Fârâbî-Mûsikî," Türkiye Diyanet Vakfi İslam Ansiklopedisi 12, (1995): 162-163. Kaynaklarda müzik ilmini öğrendiği âlimler zikredilmemekle beraber İbn Sînâ mûsikî konusunda Kindî ve İhvân-1 Safâ'nın eserlerini incelemiş; ayrıca Fârâbî’den oldukça etkilenmiştir. Ayrıntılı bilgi için bkz: Ahmet Hakkı Turabi, "İbn Sînâ ve Müzik," Uluslararası İbn Sînâ Sempozyumu Bildiriler /International Ibn Sina Symposium 2, (2009): 196.

7 Turabi, “EbûYa‘kūb b. İshâk el-Kindî’nin Müzik Risâlelerinde Tesbit Edilen Terimler," 68. 
ve oran ile irtibatlı olduğunu ifade etmektedir. Bu bilgilerden yoksun olan kişilerin nicelik ve niteliğe ait bilgiden, dolayısıyla cevher bilgisinden yoksun olacağını belirtir. Ancak bu dört ilim öğrenildikten sonra sırasıyla fizik, metafizik, ahlâk ve nefsi güzel ahlâkla eğitme konusundaki ilimlerin tedris edilmesi gerektiğine dikkat çekmektedir. ${ }^{8}$ Dolayısıyla evrendeki insicâm ve oranı ifade eden bu dört ilim, fizik ve metafiziğe açılan kapı niteliğindedir. Ayrıca bu tasnifte Kindî’nin, mûsikî ilmini ahlâkî tekâmüle ulaşmak için öncelikle öğrenilmesi gereken ilimler arasında zikrettiğine dikkat çekmek isteriz.

"İlmu't-te'lif" ifadesi ve mûsikînin bir oran teorisi olarak ele alınması fikri İhvân-1 Safâ' da da geçmektedir. İhvân, mûsikîyi "gök ve toprak arasındaki ahenk" olarak açıklar. Mûsikî risâlesini yazma amaçlarının, bu oran ve kompozisyon (te'lif) bilgisini açıklamaya çalışmak olduğunu ifade eder. Mûsikî ilmi İhvân-ı Safâ Risâleleri'nde, "rûhânî ve cismânî şeylerden oluşmuş, oranların bilgisine dair bir "te'lif" sanatı" şeklinde tanımlanır. 'Evrende bulunan bu uyum ve oran, semâvî ve felekî cisimler ile insanda ve tüm mevcûdatta bulunmaktadır. İnsan evrendeki bu düzene uyum sağladığında kendi fizik ve metafizik varlığ itibariyle de itidal sahibi bir varlığa dönüşmektedir. Mûsikî ilmi, bu noktada etkili olmaktadır. Mûsikî ilmini bir oran teorisi olarak inceleyip riyâzî ilimler içerisinde tasnif etme geleneğinin İslâm fillozofları içersinde Kindî ile başladığına da dikkat çekmek isteriz.

Mûsikînin ahlâkî tekâmüle etkisini çalışmamızda üç başlık altında inceleyeceğiz: İlk bölümde, mûsikî ilminin bir ahenk teorisi olarak semâvî cisimlerle ilişkisi; ikinci bölümde, mûskînin insanın mizacı üzerinden insan tabiatına tesiri; son bölümde, erdemlerin ortaya çıkışına etkisi bağlamında ahlâkî tekâmüle tesiri ele alınacaktır.

\section{Mûsikînin Semâvî Cisimlerle İlişkisi}

Antik Yunan düşüncesinde, güzelin duyulur dünya ile sınırlı kalmayıp metafizik boyutlarının olduğunun kabul edilmesi, sanatın Tanrı ile ilişkili olarak ontolojik bir

8 Kindî, “Aristoteles' in Kitaplarının Sayısı Üzerine, ” Felsefi Risâleler içinde, ed. Mahmut Kaya, (İstanbul: Klasik Yayınları, 2014), 272. Fârâbî’de de benzer bir tasnif görmekteyiz. İhsâu'l-ulûm isimli eserinin mûsikî kısmında bu ilmi, amelî ve nazarî şeklinde iki başlık halinde inceler. Ebu Nasr Muhammed b. Muhammed b. Tarhan el-Fârâbî, İhsâü'l-ulum, tahk. Ali Bu Mülhim, (Beyrut: Mektebetü'l-Hilal, 1996), 61; Benzer bir tasnif İbn Sina'da da görülmektedir: Ahmet Hakkı Turabi, "İbn Sina ve Müzik,” 198.

9 İhvân-1 Safâ, Resấ 'ilu İhvâni 's-Safầ ve hullâni 'l-vefầ', tahk. Arif Tamir, (Beyrut: Dâru Uveydati'dDevliyye, 1995), I, 195. İhvân'da mûsikî ve matematik arasındaki ilişki hakkında ayrıntılı bilgi için bkz: Muhammet Fatih Kılıç, "İhvân-1 Safầ'da Sanatın Ahlâki Boyutları: Müzik Üzerine Bir İnceleme,” Bilimname: Düşünce Platformu 36, no. 2 (2018), 74. 
zeminde ele alınması fikrini getirmiştir. ${ }^{10}$ Pisagorcu mûsikî anlayışının etkilediği İslâm Meşşâ̂ filozoflarından Kindî, mûsikînin gök cisimleri ve tabiatla çok yakın ilişkisi olduğunu düşünmekte, kozmolojik olayları mûsikîyle değerlendirmektedir. Kaynaklar onun bu konuda Grek, Sâbiî ve İskenderiye felsefelerinden etkilendiğini ileri sürer. Udun dört teliyle gökcisimleri, burçlar, ay, dört unsur, rüzgâr, mevsimler arasında ilişki kurar. Bütün bunların insan vücudu üzerindeki etkilerini inceler. ${ }^{11}$ Kindî’nin mûsikînin kozmolojik kökenlerini açıklama çabası, aynı zamanda ona meşruiyet kazandırma amacı da taşımaktadır.

İlkçağ felsefesinde mûsikî ile kozmolojik ilkeler arasında irtibat kuran ilk düşünür Pythagoras'tır. Mûsikîye önem veren ve sayıyı arke olarak kabul eden Pythagoras, mûsikîdeki ahengin tabiatta ve bütün olarak evrende bulunan uyumu yansıttığını, güzelliğin de ancak bu harmoni içinde değerlendirilebileceğini kabul etmiştir. Evreni harmonik bir bütün olarak düşünen Pythagoras, bu uyumu sağlayanın da sayılar arasındaki orantı olduğunu kabul etmektedir. ${ }^{12}$ Aristotales de Pisagorcuların müziğin kaynağı olarak evrendeki uyumu ve gökcisimlerinin hareketlerini kabul ettiklerini ifade eder. Müzikteki ses aralıkları ve oranlar, gökcisimlerinin uzayda dönerken -ağırlıklarına ve yörüngelerindeki dönüş hızlarına bağlı olarak- farklı ve birbirleriyle uyumlu olarak çıkardıkları seslere göre şekillenmektedir. Gökcisimlerinin çıkardıkları bu ses, ölümlü insanların kulakları tarafından duyulamaz. Duyusal müzik, bu göksel müziğin ancak bir imgesi olabilir. ${ }^{13}$ Dolayısıyla ayaltı alemdeki musîkî nağmelerinin kaynağı ayüstü alemdeki cisimlerin hareketleri ve uyumudur.

Mûsikî nağmelerinin semâvî cisimlerle ilişkisini göstermek üzere Kindî, yedi asıl perde dediği yedi nağmeyi (sesi) gökyüzündeki yedi gezegenin karş1lı̆̆ı olarak

10 Ayşe Taşkent, "İslam Felsefesinde Estetik: Güzelin Ontolojik, Kozmolojik, Psikolojik ve Mantıkî Bağlamda Değerlendirilmesi,” Din ve Hayat: Ístanbul Müftülüğü Dergisi 14, (2011), 29.

11 Turabi, "Ya'kub b. İshak el-Kindî," 58-59; Toksöz, "Kindî’nin Düşünce Sisteminde Müzikal Seslerle Âlemdeki Düzen Arasındaki İlişkisi,” 94-98. Kindî’nin bu düşüncesine karş1lık İbn Sînâ sesler arasındaki uyumu gökcisimleri ile irtibatlı olarak açılamaktan ziyade onları sayısal bir oran olarak açıklamayı tercih etmiştir. İbn Sînâ'nın mûsikî ile gök cisimleri arasındaki irtibata yönelik eleştirileri için bkz: Turabi, "İbn Sina ve Müzik," 203.

12 Ömer Özden, "Platon ve Aritoteles'in Estetik Anlayışları," Arayışlar -İnsan Bilimleri Araştırmaları 5-6, no.3 (2001): 33-44; Andrew Barker, "Pythagoras and Early Pythagoreanism," Greek Musical Writings II içinde, (New Yok: Cambridge University Press: 1989), 28-29. Kindî’nin evren tasavvuru hakkında ayrıntılı bilgi için bkz: Atilla Arkan, "Kindî ve İbn Rüşd'de İnsan Tasavvuru," İslâm Araştırmaları Dergisi 12, ( 2004), 30.

13 Ahmet Arslan, İlkçağ Felsefe Tarihi, I, 155-157; Aristotales, Metafizik (İstanbul: Sosyal Yayınlar,1996), 985b 26, 986a 14. Pisagor'un evrendeki harmoni fikrinin mûsikîye etkisi konusundaki fikirlerinin Platon'da da etkili olduğunu görmekteyiz. Bu hususta ayrıntılı bilgi için bkz: Andrew Barker, Plato, Greek Musical Writings II, 54. Platon, Devlet, çev. M.Ali Cimcöz-Sabahaddin Eyüboğlu (İstanbul: İş Bankası Yayınları, 2002) 442a. 
kabul etmiştir. Bu perdeler ve karşılıkları şunlardır: Mutlaku'l-bam Zuhal (Satürn) gezegenine, sebbâbetü'l-bam Müşteri'ye (Jüpiter), vusta'l-bam Merih'e (Mars), hınsırü'l-bam Şems'e (Güneş), sebbâbetü'l-misles Zühre'ye (Venüs), vusta'l-misles Utârid'e (Merkür), hınsırü'l-misles Kamer'e (Ay) karşl1ıktır. Kindî, bu yedi sesin oluşturduğu diziyi "usûlü'l-kibâri't-tâmme" olarak adlandırır. ${ }^{14}$ Kozmolojisinde ayüstü alemin ayaltı aleme tesirini kabul eden Kindi, bunu mûsikî nağmaleri ile semâvî cisimler arasında kurduğu irtibat üzerinden açıklamaya çalışmaktadır.

Kindî udun tellerinin dört tane oluşunu ontolojik âlemle irtibatlı olarak pek çok açıdan izah eder: "Anâsır-1 erbaa dörttür. Dört 1şık kaynağı vardır; güneş, ay, yıldızlar ve ateş. İnsanda dört temel duyu (koklama, görme, işitme, tad alma) olduğunu ifade eder. Yine insanda ahlâkî açıdan da dört temel fazilet vardır: Hikmet, iffet, şecaat, adalet. Buna karşl1ık dört tane ritim (sakil, hafif, remel, hezec) bulunmaktadır." ${ }^{15} \mathrm{Bu}$ ritimlerin insana faziletleri hatırlattığına pekçok yerde dikkat çeker. Aynı şekilde udun tellerinin renkleri, sıra düzeni ve şekli kozmik düzenle irtibatlı olarak açıklanır.

Benzer şekilde neyde 10 delik bulunmasının sebebini kozmolojik irtibatları ile açıklar. İnsandaki harflerin mahreçlerinin çıkış yerlerinin ve benzer şekilde âlemdeki kürelerin de on tane olduğunu ifade eder: İlk hareket küresi, sabit y1ldızlar küresi, Satürn küresi, Jüpiter, Mars, Güneş, Venüs, Merkür, Ay, Hava-Ateş Küresi, SuToprak Küresi. Cevher, araz, nicelik, nitelik, zaman, mekân, hal, heyet, illet, malül olmak üzere eşyada on kategori bulunmaktadır. ${ }^{16}$ Pisagorcu evren tasavvurunda da benzer şekilde 10 sayısı mükemmel ve tüm sayıların doğasını içinde bulunduran bir sayı olarak ifade edilir ve gökcisimleriyle irtibatlandırılır. ${ }^{17}$

Mûsikînin felekleklerle irtibatlı olarak düşünülmesi fikri İhvân-1 Safâ'da da benzer şekilde ele alınmaktadır. Mûsikînin aslında felekî şahısların sesleri ve nağmeleri olduğu belirtilmektedir. Gökcisimlerinin birbirlerine uzaklıkları ve hareketleri mükemmel bir oranla uyum içerisinde gerçekleşmektedir. Bu hareketlerin de yine uyumlu, çarpıcı, leziz nağmeleri vardır. Ud tellerinin hareketleri ve nağmeleri de bu uyumu yansıtması hasebiyle güzel nağmeler ortaya çıkarır. Bu nağmelerin farkına

14 Kindî, "Kitâbu'l-musavvitat," Müellefâtü 'l-Kindîyyi'l-Mûsikîyye içinde, tahk. Zekeriyya Yusuf (Bağdad: 1962), 86-87; Turabi, "Ya'kub b. İshak el-Kindî," 58-59. Kindi'nin metafizik düşüncesi hakkında ayrıntılı bilgi için bkz: Ömer Türker, "Kindî Metafiziği," Diyanet İlmi Dergi 54, no.2 (2018): 53-66.

15 Kindî, "Kitâbu'l-musavvitât,” 76; Turabi, “el-Kindî’nin Mûsikî Risâleleri,” 140.

16 Kindî, "Kitâbu'l-musavvitat," 91; Turabi, “el-Kindî’nin Mûsikî Risâleleri,” 155.

17 Ahmet Arslan, İlkçăg felsefe Tarihi, I, 155; Aristotales, Metafizik, 985b 26, 986a 14. 
varan kimsenin nefsi, oraya yükselmek, onu dinlemek ve görmek ister. ${ }^{18}$ Aslında feleklerin hareketleri esnasında sesler çıkarmaları fikri Pythagorasçı düşüncenin İslam düşünce dünyasındaki yansıması olduğunu ifade etmiştik. Bu fikri eserlerine yansitan ilk filozof olan Kindî’nin İhvân'ın düşünce sisteminde etkili olduğunu ifade edebiliriz. Semâvâtın ve feleklerin sekeneleri olan meleklerin mûsikî aletleri gibi fakat bu aletlerden çok daha hoş nağmeleri bulunduğu; dünyadaki nağmelerin bu ideal nağmelerin birer kopyası olduğu fikri Risâleler' de şöyle ifade edilmektedir:

"Kevn âleminde düzenli hareketler ve bu hareketlerden neş'et eden uyumlu sesler olduğu gibi felekler âleminde de bu kesintisiz düzenli hareketlerin nağmeleri vardır. Bunlar birbirleriyle son derece uyumlu, nefisleri ferahlatan ve daha üst seviyelere yükselmeye teşvik eden nağmelerdir. Nitekim çocukların tabiatında anne-babalarının, ögrencilerin de hocalarının, halkın sultanlarının, akıl sahiplerinin meleklerin hallerine iştiyakı ve onlara benzeme istekleri vardır. Felsefenin tanımında belirtildiği gibi bu durum, insanın gücü nispetinde ilaha benzeme çabasıdır. Hakîm Pisagor, kendi cevherinin sâfiyeti ve kalbinin zekâslyla yıldız ve gezegen hareketlerinin nağmelerini işitmiştir. ... Bu amaçla hikmet sahipleri, müzikal makam ve melodileri tapınaklarda, mabedlerde, kurban merasimlerinde kullanmışlardır. Böylelikle gaflet içinde olan nefislere ve umarsız ruhlara aslında ait oldukları rûhânî âlemin sevincini, nûrânî alemlerin mekânını ve asıl varoluş yurtlarını hatırlatmışlardır." 19

Mûsikî ile rûhânî âlemler arasında kurulan bu irtibat, insanın bu âlemlere yönelerek kemâle ulaşma amacina hizmet etmektedir.

Kindî’nin ontolojisinde gökcisimleri, ayaltı alemdeki varlıkları oluşturan dört unsur ve dört niteliğin oranına etki ederek farklı varlıkların oluşmasını sağlamaktadır. Benzer şekilde insan nefsinin oluşumunda da etkilidirler. Bedenimizin döllenme sırasında ve döl yatağında kazandığı yapıya (mizac), bu cisimlerin hareketleri tesir etmektedir. Mesela ekvator bölgesinde yaşayan insanların fiziksel yapılarının farklı oluşundan bahsederek, bu insanların aşırı sıcak sebebiyle öfkeli ve saldırgan olduklarını, bundan dolayı da görüşlerinin daima değişkenlik arzettiğini ifade eder. ${ }^{20}$ Diğer varlıklarda olduğu gibi insan bedenini oluşturan ahlât-1 erbaa ve dört niteliğin

18 İhvân-1 Safâ, Resâ'ilu İhvâni 's-Safâ ve hullâni'l-vefầ', I, 225; İhvân-1 Safâ, "Mûsikî Risâlesi," İhvân-ı Safâ Risâleleri içinde, terc. Ahmet Hakkı Turabi, ed. Abdullah Kahraman, İsmail Çalışkan (İstanbul: Ayrıntı Yayınları, 2012), I, 152; Süleyman Uludağ, İslam Açısından Mûsikî ve Sema (İstanbul: 1992), 352; K1lıç, "İhvân-1 Safâ'da Sanatın Ahlâki Boyutları: Müzik Üzerine Bir İnceleme," 77-79.

19 İhvân-1 Safâ, Resâ 'ilu İhvâni 's-Safâ ve hullâni 'l-vefâ', I, 213; Risâleler I,144. İhvân seslerin kişiye gök cisimlerinin ahengini çağrıştırdığını şöyle ifade eder: "Müzisyenin telinin vuruşlarının vezni, aralarındaki ahenk ve seslerinin lezzeti, cüz'î nefislere yıldız ve gezegenlerin hareketlerinin ahenkli ve tatlı bir kompozisyon olduğunu bildirir." İhvân-1 Safâ, Resâ'ilu İhvâni 's-Safâ ve hullâni'l-vefâ', I, 234; Risâleler, I, 158.

20 Kindî, "Oluş ve Bozuluşun Yakın Etkin Sebebi Üzerine," Felsefi Risâleler içinde, ed. Mahmut Kaya (İstanbul: Klasik Yayınları, 2014), 216. 
oranı gökcisimlerinin hareketlerinden etkilenmektedir. Bu durum da dolaylı olarak insanların ahlâkına tesir etmektedir.

"Risâle fi Eczâi Hubriyye fi 'l-Mûsîka" isimli risâlesinde Kindî, udun telleriyle mevsimler, dört unsur ve insan bedenindeki dört sıv1 arasında irtibat kurar: ${ }^{21}$

Zîr teli, feleğin gökyüzünün ortasındaki ilk cüzünden Mağrib'deki cüzünün sonuna kadar olan çeyreğine; ayın ilk dördünden doğmasına kadar olan çeyreğine, tekâbül eder. Unsurlardan ateşe, rüzgarlardan güney rüzgarına, mevsimlerden yaza tekâbül eder. Ayın yedinci gününün başından 14. gününe kadar olan çeyreğine; günün öğle yarısından güneş yuvarlağının yarısının batması vaktine tekâbül eder. Vücudun rükünlerinden safrâya; insan ömrünün ilk gençlik çeyreğine; nefsin zihinsel güçlerinden düşünme gücüne, bedensel güçlerinden câzibe gücüne münasiptir. Nefsin zahiri fiilerinden şecaate tekabül etmektedir. ${ }^{22}$

Udun tellerinin çıkardığı diğer melodiler ve kozmik varlıklarla irtibatını şu şekilde tablolaştırabiliriz:

\begin{tabular}{|l|l|l|l|l|}
\hline & Gök Cisimleri & Mevsim & Anâsır-ı Erbaa & Ahlât-ı Erbaa \\
\hline Zir Teli & Mars & Yaz & Ateş & Sarı Safra \\
\hline Mesnâ Teli & Jüpiter & İlkbahar & Hava & Kan \\
\hline Misles Teli & Venüs & Sonbahar & Toprak & Balgam \\
\hline Bam Teli & Satürn & Kış & Su & Kara Safrâ \\
\hline
\end{tabular}

Kozmik bir bütün olarak düşünülen evrende gökcisimlerinin hareketleriyle irtibatlandırılan mûsîkî nağmeleri, udun telleri üzerinden mevsimlerle, evrendeki dört unsurla karşılaştırılmıştır. Bu nağmeler ayaltı alemdeki tüm varlıklara olduğu gibi insanın bedensel sıvılarının oranına da tesir etmektedir. Bu durum, huylara da etki ederek insanın ahlâkî erdemleri elde etmesinde önemli bir rol oynamaktadır.

\section{Mûsikînin İnsan TabiatınaTesiri}

Semâvî cisimlerin hareketleri insan başta olmak üzere ayaltı alemdeki tüm varlıkların oluşumuna tesir etmektedir. Ayaltı alemdeki tüm varlıklar dört unsurdan oluşmakta, basitten mürekkebe doğru bir kemâl seyri takip etmektedir. İnsan da bu oluşumunu diğer varlıklarla birlikte hem fiziksel açıdan hem de metafizik açıdan gerçekleştirmektedir. Mûsikî bu noktada insanın hem fiziksel hem de metafizik kemâli açısından etkili olmaktadır. Mûsikî nağmeleri, insanın bedenindeki sıvıların oranına tesir ederek mizacını etkilemekte, bu da huyları, buna bağlı olarak ahlâkı değiştirmektedir. Bu şekilde mûsikî insanın fiziksel yapısı üzerinden ahlâki kemâle etki etmektedir. Metafizik yapısı açısından baktığımızda ise ayüstü âlemdeki semâvî cisimlerin hareketlerinden ortaya çıkan harmoni, ayaltı âlemdeki müzik

21 Kindî, "Risâle fi Eczâi Hubriyyefi'l-Mûsîka,” 100; Turabi, “el-Kindî’nin Mûsikî Risâleleri,” 163.

22 Kindî, "Risâle fi Eczâi Hubriyyefi'l-Mûsîka," 100-102; Turabi, "el-Kindî’nin Mûsikî Risâleleri," 164-165. 
nağmeleriyle irtibatlandırılmaktadır. Bunun sonucunda bu nağmeleri dinleyen insan göksel varlıkları ve metafizik âlemleri hatırlayacak ve oraya iştiyak duyacaktır. Bu durumda insan maddi âlemin etkisinden uzaklaşıp metafizik âlemlere yönelecektir ki ahlâkî kemâle ulaşmanın en temel yolu budur.

Kindî ahlâk felsefesini, insanın düalist yapısına işaret eden nefis ve kuvveleri konusundaki görüşleri üzerine inşa etmiştir. Platon'un idealizmi ile Aristo'nun realist tavrı Kindî’nin bu mesele etrafindaki görüşleri çerçevesinde meczedilmiştir. Kindî nefsin tanımında, nefsin daha ziyade fonksiyonlarını ifade eden "tabî̀ cismin ilk yetkinliği" ${ }^{23}$ şeklindeki Aristocu tanımla; nefsin mahiyetine işaret eden "cisimden bağımsız basit bir cevher oluşu" 24 şeklindeki Platoncu tanımı birlikte zikreder. Kuvveler hususunda da Platon' daki; akıl, öfke ve arzu güçleri şeklindeki üçlü tasnifi benimser. ${ }^{25}$ Bununla birlikte risâlelerinin farklı yerlerinde; duyu (hass, hiss), hafıza, tevehhüm, vehm ve musavvire (mütehayyile gücünün karşıllğı), ihtiyar ve akıl şeklinde ifade ettiği Aristocu tasnifi de ele alır. ${ }^{26}$ Ahlâkî tekâmül için gerekli olan bilme sürecini, insanın düalist yapısı ile paralel olarak ele aldığ 1 fizik ve metafizik âlemlerle irtibatlı olarak bu kuvveler çerçevesinde inceler. ${ }^{27}$ Kindî, mûsikînin insan tabiatına tesirini insanın fiziksel ve zihinsel kuvvelerine etkisi itibariyle ele almaktadır.

Mûsikînin insanın fiziksel tabiatına tesirini Kindî, vücuttaki ahlât-1 erbaanın oranına dolayısıyla mizaca etkisi itibariyle incelemektedir. Bir önceki bölümde udun telleri ile ahlât arasında yaptı̆̆ 1 karşılaştırmaya değinmiştik. Gökcisimlerinin seslerinin benzeri olan mûsikî nağmeleri, vücuttaki sıvıların oranını dengelemekte, bu denge hali hem insanın fiziksel olarak kemâle ulaşmasını, hem de sağlıklı olmasını sağlamaktadır. İnsanın ruh ve beden yapısını her zaman birbiriyle insicam içinde düşünen Kindî’ye göre bu denge hali insanın huylarına ve dolaylı olarak ahlâkına da tesir etmektedir. İslam felsefesinde Kindî başta olmak üzere anâsır-1 erbaa anlayışı antik Yunan düşüncesinden gelmektedir. İlk olarak Hipokrat ve Galen tarafından ele alınan ahlât-1 erbaa teorisi Pisagor ve takipçileri tarafindan da

23 Aristotales, Ruh Üzerine, terc. Zeki Özcan (İstanbul: 2001), II/1, 412b.

24 Eflatun, Timaios, terc. Erol Güney, Lütfi Ay (İstanbul: 2001), 45, 46d.

25 Platon, Devlet, 436b, 114.

26 Aristo, Ruh Üzerine, 72, II, 2, 20; II, 2, 3, 30. Kindî, "Risâle f'l-Hudud ve'r-Rusum," Felsefi Risâleler içinde, 180, 181, 186, 187, 188; "İlk Felsefe Üzerine", 131; Kindî, "Risâle fỉ Eczâi Hubriyyefi'l-Mûsîka," Müellefâtü'l-Kindîyyi'l-Mûsikîyye içinde, 100-102; Turabi, “el-Kindî’nin Mûsikî Risâleleri," 164-165.

27 Gökcisimlerinin insan tabiatına (mizâcına) dolayısıyla ahlâkına tesiri hakkında ayrıntılı bilgi için bkz: Kindî, “Kitabi'I-Kindî fi'l-ibaneti ani'l-'illeti'l-fa'1leti'l-karibeli'l-kevn ve'l-fesad," Felsefi Risâleler içinde, 217. 
incelenmiştir. ${ }^{28}$ Pisagorasç1lığın temsilcilerinden Alkmeon bu uyum düşüncesini tıbba uygular. İnsanın sağlık durumu dört niteliğin vücutta eşit oranda bulunmasıyla mümkün olduğunu ifade eder. Hastalık ise bu oranın bozulmasıdır. Hekimin görevi bu armoniyi yeniden sağlamaktır. ${ }^{29}$

Kindi de udun tellerinin çıkardığı sesleri doğrudan ahlât ile karşılaştırarak mizaca etkisini incelemiştir. Buna göre zîr teli sarı safraya, mesnâ teli kana, misles teli kara safrâya, bam teli balgama tesir ederek bu sıvıların oranını etkilemektedir. ${ }^{30} \mathrm{Bu}$ durum, hem bedenin fiziksel açıdan sağlığına hem de metafizik açıdan ahlâkına tesir etmektedir. Bu konuyu incelediği bir başka yerde uda, zîr telinin altına had ismiyle beşinci bir tel daha bağlayanlar olduğunu, bu beş telin insandaki beş zâhirî ve beş bâtınî duyuya işaret ettiğini belirtir. Zâhirî olanlar beş duyu, bâtınî olanlar; düşünme, hatırlama, zihin, ayırt etme ve anlama duyularıdır. ${ }^{31} \mathrm{Bu}$ ifadesiyle Kindî, mûsikînin mîzaç üzerinden insanın bedenine olduğu kadar, aynı zamanda insanın zihinsel melekelerine de tesiri olduğuna dikkat çekmektedir. Bilme sürecine olan bu etki huyların oluşumuna doğrudan tesir etmekte, erdemler ya da erdemsizliklerin meydana gelmesinde de etkili olmaktadır.

Ahlâkî tekâmül için esas olan hakikatin bilgisine ulaşma serüveninde en önemli husus Kindî’nin Platon ve Pisagorcu bakış açısıyla ele aldığı "arınma" fikridir. ${ }^{32}$ Platon'daki gibi, köpeğe ve domuza benzettiği arzu ve öfke gücünü aklın dizginleyebilmesi ancak nesneler âleminden uzaklaşmakla mümkündür. Eğer insanda aklî nefis gücü üstün gelir, böylece tefekkür ve temyiz kabiliyetini kazanır, varlığın hakikatini bilme ve ilmin derinliklerini araştırmayı alışkanlık haline getirirse o kimse şanı yüce Yaratıcı'ya yakın benzerlikte faziletli bir insan olur. ${ }^{33}$

28 Ahlât-1 Erbaa teorisi hakkında ayrıntılı bilgi için bkz: Ayşegül Demirhan Erdemir, "Anâsır-1 Erbaa," Türkiye Diyanet Vakfi 2, (1989): 24. Galen bir tıp teorisi olarak mizacı insan tabiatı ve ahlâkla ilişkilendirerek ele almıştır: Galen, Kuva'n-Nefs Tevâbi'li Mizâci'l-beden, tahk: Abdurrahman Bedevî (Beyrut: el-Müessesetü'l-Arabiyye li'd-Dirasat ve'n-Neşr, 1981), 184. Platon da sağlığın bu dört sıvının harmonisinin sağlanmasıyla mümkün olduğunu ifade eder: Andrew Barker, "Plato," Greek Musical Writings II içinde, 39.

29 Arslan, İlkçă̆ Felsefe Tarihi, I, 158. Aristotales de insan bedenindeki bu armoniyi oran olarak ifade etmektedir: Aristotales, Ruh Üzerine, 408a, 5-15.

30 Kindî, "Risâle fi Eczâi Hubriyyefi'l-Mûsîka," 100-102; Turabi, "el-Kindî’nin Mûsikî Risâleleri," 164-165.

31 Kindî, "Kitâbu'l-musavvitat," 78: Turabi, "el-Kindî’nin Mûsikî Risâleleri," 142. Aynı karşıllaştırmayı İhvân'da da görebiliyoruz: İhvân-1 Safâ, Resâ'ilu İhvâni 's-Safâ ve hullâni'lvefâ', I, 216; Risâleler, I, 146.

32 Pisagorculuktaki arınma fikri hakkında bkz: Andrew Barker, "Pythagoras and Early Pythagoreanism", 28. Platon, mağara alegorisinin sonunda ideaların bilgisine ulaşabilmek için gölgelerden kurtulup, İyi ideasına yönelmemiz gerektiğini belirtir. Ruhu değişen varlıktan gerçek varlığa ulaştıracak bilimin ise, müzik olduğunu ifade eder: Platon, Devlet, 517c, 521d.

33 Kindî,"Risâle f'l-Hudud ve'r-Rusum," 246. 
İşte mûsikî, insanın yönünü nefsinin asıl vatanı olan yüce âlemlere döndürmesi, bu dünyadan soyutlanmasını sağlaması itibariyle onun kemâli elde etmesinde çok önemli bir rol oynamaktadır.

Kindî, her milletin enstrümanının düşünce sistemine göre farklılık arzettiğini belirterek musikinin insan tabıatıla irtibatına dikkat çeker. Hintlilerin enstrümanında bir tel bulunurken, İranlılarınkinde iki, Rumların estrümanının ise üç telli olduğunu ifade eder. ${ }^{34}$ Her milletin farklı enstrümanlar icat etmesi karakterle mûsikî arasindaki insicâma işaret etmektedir.

\section{Mûsikînin Ahlâkî Tekâmüle Tesiri}

Semâvî cisimlerin seslerine benzer şekilde belirli bir oransal uyum üzerinde bir araya gelen müzik melodileri, insanın davranışlarında olumlu tesirler bırakarak ahlâkî erdemlerin oluşmasını sağlamaktadır. Bu oransal uyumun bulunmadığı sesler de tam tersi bir etkiye sebep olmakta, erdemsizlikleri insana hatırlatmaktadır. Kindî udun tellerinin gökcisimleri ve burçlar üzerinden insanın mizâcına, nefsin idrak güçlerine ve ahlâkına etkisini şöyle izah eder:

"Zîr teli bir ruhtur. Cismi yoktur. Gökyüzünün ortasındaki cüzün ilk feleğinin çeyreğine eştir. Bu çeyreğin rengi sarıdır. Burçların bir çeyreği olan ateş unsurlu üç burca eştir... Gezegenlerden Mars' $a$, unsurlardan ateşe, rüzgarlardan güney rüzgarına, yönlerden doğuya, mevsimlerden yaza....vücudun rükünlerinden safraya, ömrün ilk gençlik çeyreğine, bedenin ana organlarında kalbe, nefsin güçlerinden düşünme gücüne, bedendeki güçlerden sicaklık ve kurulukla işlev gören cezbedici güce, bir canlıdaki fiillerden kahramanlık, mertlik, şiddet, saldirganlık, kibir, cesaret, atılganlık ve inatçılık gibi fiillere eştir." ${ }^{35}$

Benzer şekilde tellerin anâsır-1 erbaa, ahlât-1 erbaa ve nefsin güçleriyle ilişkisi ve bu ilişki sonucunda ortaya çıkan erdemler şu şekildedir:

\begin{tabular}{|l|l|l|l|l|l|}
\hline & $\begin{array}{l}\text { Anâsır-I } \\
\text { Erbaa }\end{array}$ & $\begin{array}{l}\text { Ahlât-ı } \\
\text { Erbaa }\end{array}$ & $\begin{array}{l}\text { Nefsin Zihinsel } \\
\text { Güçleri }\end{array}$ & $\begin{array}{l}\text { Nefsin } \\
\text { Bedensel } \\
\text { Güçleri }\end{array}$ & $\begin{array}{l}\text { Nefsin } \\
\text { Zâhirî } \\
\text { Fiilleri }\end{array}$ \\
\hline Zir Teli & Ateş & Sarı Safra & Düşünme/Fikriyye & Câzibe & Şecaat \\
\hline Mesnâ Teli & Hava & Kan & Tahayyül & Hâzime & Adalet \\
\hline Misles Teli & Su & Balgam & Hatırlama & Dâfia & İffet \\
\hline Bam Teli & Toprak & Kara Safrâ & Hâfıza & Mâsike & Hilm \\
\hline
\end{tabular}

34 Kindî, "Kitâbu'l-musavvitat,” 73,74; Turabi, “el-Kindî’nin Mûsikî Risâleleri,” 137,138; Kindî, Risâle fi'l-luhûn ve'n-nağam, tahk. Zekeriyya Yusuf(Bağdad: Matbaatü'ş-Şefik, 1965), 26; Turabi, "el-Kindî’nin Mûsikî Risâleleri," 188. İhvân-1 Safâ da her mizacın kendine has bir makamı ve nağmesi olduğu gibi, her milletin de kendisine has bir melodisi ve makam sistemi olduğunu risâlelerin farkl1 yerlerinde vurgular. İfadeler ve örnek verilen milletler Kindî ile benzerlik arzetmektedir: İhvân-1 Safâ,, Resâ'ilu İhvâni 's-Safâ ve hullâni'l-vefầ', I, 204, 232; Risâleler, I, 137,157.

35 Kindî, “Kitâbu'l-musavvitat,” 86-87; Turabi, “el-Kindî’nin Mûsikî Risâleleri,” 150-151. 
Tabloya göre zîr telinin nağmesi, sarı safrayı kuvvetlendirir, onun gücü ve etkisini arttırır. Mesna telinin nağmesi kanı kuvvetlendirir, onun etki ve gücünü arttırır. Misles telinin nağmesi balgamı kuvvetlendirir, onun güç ve kuvvetini arttırır. Bam telinin nağmesi ise kara safrayı güçlendirir, onun kuvvet ve tesirini arttırır. Bu şekilde vücudun sıvıları dengelenmektedir.

Bu sistemde Kindî, tellerin nağmelerinin evrende dört unsura ve insan bedenindeki dört sıvıya tesir ederek bedenin fiziksel yapısını etkilediğini göstermektedir. Mûsikî sayesinde vücut sıvıların dengeli olması, nefsin bedensel güçlerine tesir ederek organların çalışma sistemine de etki etmektedir. Tablodaki örneklerde özellikle bedenin sindirim sistemi üzerinde mûsikînin etkisi gösterilmektedir. Bu sıvıların oranı düzgün olursa beden sağlıklı olmaktadır. Kindî bu bakış açısıyla mûsikînin bir tedavi yöntemi olarak tıpta kullanılması gerektiğini de ifade eder. ${ }^{36}$ Kindî’nin etkisi İhvan-1 Safa'da da görülmekte olup, onların bu mediko-müzikal sistemleri Ortaçağ Avrupası boyunca ve günümüzde hastanelerde ve insanların tedavisinde kullanılagelmektedir. Kindî mûsikînin sadece insan değil, hayvanlar üzerinde de tesiri olduğunu ifade eder: "Öyle tür mûsikîler de vardır ki, insan bunları işittiğinde nefsi boşalır ve ölür, harpte kahramanlaşır, bazen sevinir bazen üzülür. Bunlar hayvanlara da aynı şekilde tesir eder." ${ }^{37}$ İnsanlarda olduğu gibi hayvanların bedenindeki imtizac da mûsikî nağmelerinden etkilenmektedir. Bunun sonucunda davranışlarında farklılıklar olmaktadır.

Tabloda nefsin, zihinsel güçleri üzerindeki etkisine yapılan vurgu ise insanın akletme melekesi üzerindeki tesirine işaret etmektedir. Zihinsel güçler üzerindeki olumlu etki, davranışlara da yansımakta ve erdemler ortaya çıkmaktadır. Tabloda yer alan erdemler farklı yerlerde farklı şekillerde ifade edilmiştir. Burada örnek teşkil etmesi açısından birini tercih ettik. Buna göre zîr telinin nağmesi şecaat erdemini, mesnâ teli adalet erdemini, misles teli iffet erdemini, bam teli hilm erdemini insanda ortaya çıkarmaktadır. Bu şekilde semâvî cisimlerin seslerine benzer şekilde belirli bir oransal uyum oluşturan müzik melodileri, insanın hem davranışlarında hem de ahlâkî yapısında olumlu tesirler bırakmaktadır.

Kindî bir başka risalesinde, mesnâ telinin insanın kanını, tabiatını, hareketlerini, letafet ve seciyelerini kuvvetlendirdiğini, kara safranın azgınlığını kırarak, onu itaat altına alıp fiillerine engel olduğunu ifade eder. Bunun sonucunda kişide sevinç, neşe,

36 Kindî, "Kitâbu'l-musavvitat,” 86-87; Turabi, “el-Kindî’nin Mûsikî Risâleleri,” 150-151.

37 Kindî, “Kitâbu'l-musavvitat,” 71; Turabi, “el-Kindî’nin Mûsikî Risâleleri,” 93, 135-136. İhvân'1n mûsikînin tıp ilmi ile ilişkisi ve tedavi yöntemi olarak kullanılmasıyla ilgili ayrıntılı bilgi için bkz: Muhammet Fatih Kılıç, "İhvân-1 Safầda Sanatın Ahlâki Boyutları: Müzik Üzerine Bir İnceleme,” 81. Kindî’nin mûsikî ile tedavi yöntemlerinin bugün modern tıpta benzer yöntemlerle yapılan tedavilere önderlik ettiği farklı düşünürler tarafından ifade edilmektedir: Bkz. Hilmi Ziya Ülken, “Irak’ta Bağdat ve Kindî’nin 1000. Y1ldönümü Anma Töreni,” AÜIFD 10, (1962). 
ferahlık, iyilik, cömertlik, tenezzül, asalet ve incelik erdemleri ortaya çıkmaktadır. Misles teli ise balgamı hareketlendirir ve onun itidalini artırır. Aynı zamanda safrayı teskin eder, onun hakimiyetini engeller. Bunun sonucunda kişide hüzün duygusunu çağrıştırır. Bam teli kara safrayı kuvvetlendirir, kanı dinidirir. Böylelikle ferahlık, sevinç, sevgi duygularını çağrıştırır. ${ }^{38}$ Tellerin seslerinin karışımı durumunda ise, farklı duygular ortaya çıkmaktadır:

"Tellerin sesleri kendi aralarında karıştırılacak olsa, bu karışım dört taabiatın karışımı gibi olur ve kişinin davranışlarında tek başlarına iken bıraktıklarının aksine tesirlerde bulunurlar. Mesala zîr ve meslesin karışımı, korkaklık ve cesaretin karışımı gibidir. Bu da itidaldir. Böylece o ikisinin arasında ahenk gerçekleşmiş olur. Mesna ve bam tellerinin karışımı sevinç ve hüzün karışımı gibidir. Bu da itidaldir. Böylece o ikisinin arasında ahenk gerçekleşmiş olur ... Zîr telinin kişide oluşturduğu davranış, cesarettir. Sahiplenme, iyilik, cömertlik de cesaretin tabiatındandır. Akıl, mesnânın tabiatındandır. Sevinç, lezzet, aşk ve güzel ahlâk da aklın tabiatındandır. Korkaklık mislesin tabiatındandır. Alçaklık, cimrilik, pişmanlık, sefalet de korkaklı̆̆ın tabiatındandır. Hilm bam telinin tabiatındandır. Sevinç, hüzün, ümitsizlik, hastalık, solgunluk da hilmin tabiatındandır. ${ }^{39}$ Seslerin ahlâta tesiri mizaca etki etmekte, bu da kişinin huylarına sirayet etmektedir. Bu tesir devaml olduğunda bir süre sonra nefiste yerleşik huylara dönüşmektedir. ${ }^{40}$

Burada aynı zamanda bu nağmelerin devamlı dinlenmesi durumunda kişinin mizacında kalıcı tesirler bırakacağı ve yerleşik huylara ve ahlâka dönüşeceğine de işaret edilmektedir.

Mûsikînin kişinin ahlâkı üzerindeki etkisini açıkladıktan sonra Kindî, "Mûsikî ile Alakalı Cüzler Üzerine" isimli risâlesinin sonunda filozofların mûsikî eğitiminin önemiyle ilgili sözlerini aktarır. Aynı örnekler İhvân-1 Safâ’nın mûsikî risâlelerinin sonunda da yer almaktadır. Kindî "fillozoflardan biri der ki” diyerek şöyle bir aktarımda bulunur:

"Nefis kendini bıraktığında hüzünlü nağmeler terennüm eder ve kendi yüce âlemini hatırlar. Bu tabiatı görüp tanıdı̆̆ında ise her şekliyle ona ârız olur. Tamamen ona ulaşıncaya kadar herşey birer birer nefse sunulur. Böylelikle yüce bir mûsikî icra edilmiş ve sağlam melodiler üretilmiş olur. Bunun içinde nefis tabiatla birlikte akar gider. Bu durum nefis, aklî lezzetler denizine dalana kadar aynı şekilde devam eder... Nefisler cismani arzularından saflaşıp, tabiatın lezzetlerini terkedince ve heyûlânî sesler sone erince, hüzünlü melodiler terennüm etmeye başlar, yüce olan rûhânî âlemini hatırlar ve o yöne arzu duyar."

38 Kindî, "Kitâbu'l-musavvitat," 88, 89; Turabi, "el-Kindî’nin Mûsikî Risâleleri," 152-153; Kindî, "Risâle fi Eczâi Hubriyyefi'l-Mûsîka,” 102; Turabi, “el-Kindî’nin Mûsikî Risâleleri,” 165.

39 Kindî, "Risâle fi Eczâi Hubriyyefi'l-Mûsîka," 103; Turabi, "el-Kindî’nin Mûsikî Risâleleri," 166.

40 Kindî, "Risâle fi Eczâi Hubriyyefi'l-Mûsîka," 102; Turabi, "el-Kindî’nin Mûsikî Risâleleri," 165.

41 Kindî, "Risâle fi Eczâi Hubriyyefi'l-Mûsîka," 109; Turabi, "el-Kindî’nin Mûsikî Risâleleri," 172. Aynı ifadeyi İhvân'da da görürüz: İhvân-1 Safâ, Resâ 'ilu İhvâni 's-Safâ ve hullâni 'l-vefầ', I, 233; Risâleler, I, 158. Grek filozoflarından Platon, eserlerinde mûsikî ile eğitim konusunu pek çok yerde ele almış; müziğin armoni ve ritim yoluyla uyumlu ve düzenli olmayı öğreteceğini, aklı keskinleştirip öfkeyi yatıştıracağını ifade etmiştir: Platon, Devlet, 119, 190. 
Nefsin mûsikî nağmeleri eşliğinde cismânî alemlerden rûhânî alemlere yönelişine dikkat çekilmektedir.

İhvân da hikmet sahiplerinin müzikal makamları ve melodileri, tapınaklarda, mabedlerde ve kurban merasimlerinde kullandıklarını ifade eder. Bu maksatla katı kalpleri yumuşatacak şekilde hüzünlü melodileri kullanmışlardır; böylelikle gaflet içinde olan nefislere ve umarsız ruhlara aslında ait oldukları rûhânî âlemin sevincini, nûrânî âlemin mekânını ve asıl varoluş yurtlarını hatırlatmışlardır. ${ }^{42}$ Burada, mûsikînin insana "kendi yüce âlemi" dediği metafizik âlemleri hatırlattığını, bu lezzetlerle hemhâl olmasını sağladığını belirtmektedir.

Udun tellerinin insanda ortaya çıkardığı olumlu duygu ve davranışlar olduğu gibi, gökcisimlerine benzer şekilde oransal uyumun olmadığı nağmeler kişide olumsuz duyguları da çağrıştırabilmektedir. Örnek olarak mesnâ teli, korkaklık, sefillik, zayıflık, pişmanlık gibi olumsuz duyguları çağrıştırabilir. Bam teli bozuk ve değişken düşünceleri hatırlatarak kişinin kendini bırakmasına sebep olur. ${ }^{43}$ Mûsikînin nefisler üzerindeki olumsuz tesirlerine dikkat çekmek üzere bir başka yerde Kindi şunları söyler: "Mûsikî dinlerken tabiatın süsü türünden hayvânî nefsin şehvetlerinin sizi etkisi altına almasından sakınınız. Zira ayağınızı hidayet yollarından kaydırı, sizi yüce nefsin münacaatından alıkoyar." ${ }^{44}$ İhvan da müziğin bazı peygamberlerin şeriatlarında haram kılınmasını sebebini, insanların onu hikmet sahiplerinin yaptığı gibi değil de oyun ve eğlence yolunda, dünya lezzetleri ve arzularına rağbet etmede ve gururlanma konularında kullanmaları şeklinde açıklar. ${ }^{45}$ Her iki filozof da yanlış maksatlarla kullanılan mûsikînin insana olumsuz duyguları çağrıştırabilceğine dikkat çekmektedir.

Mûsikînin kozmolojik kökenlerini açılama çabası, aynı zamanda ona meşruiyet kazandırma amacı da taşımaktadır. Semâvî cisimlerin seslerine benzer şekilde belirli bir oransal uyum üzerinde bir araya gelen müzik melodileri, insanın hem davranışlarında hem de ahlâkî yapısında olumlu tesirler bırakmaktadır. Bu oransal uyumun bulunmadığı sesler de tam tersi bir etkiye sebep olmaktadır. Meşru olan

42 İhvân-1 Safâ, Resâ'ilu İhvâni 's-Safâ ve hullâni'l-vefầ', I, 213; Risâleler , I, 144.

43 Kindî, "Kitâbu'l-musavvitat," 89; Turabi, “el-Kindî’nin Mûsikî Risâleleri,” 153.

44 Kindî, "Risâle fi Eczâi Hubriyyefi'l-Mûsîka," 108; Turabi, "el-Kindî’nin Mûsikî Risâleleri," 171; Bu örnekler İhvân-1 Safâ Risâleleri'nde aynen geçmektedir. İhvân-1 Safâ,, Resâ'ilu İhvâni s-Safâ ve hullâni'l-vefâ', I, 232, 233; Risâleler, I, 157, 158.

45 İhvân-1 Safâ, Resâ'ilu İhvâni 's-Safâ ve hullâni'l-vefầ', I, 214; Turabi, "Mûsikî,” 145. Mûsikînin İslam hukuku açısından meşru kabul eden ve etmeyenlerin gerekçeleri ve görüşleri hakkında ayrıntılı bilgi için bkz: Yasin Kurban, "İnsan Tabiatı ve İslam Açısından Müzik (Müzik-Fıtrat İlişkisi),” Atatürk Üniversitesi Sosyal Bilimler Enstitüsü Dergisi 23, no. 1 (2019): 27-30, 33. 
ve insanın ahlâki yetkinliğini sağlayan müzik ilahi yasalarla da uyumlu olmalıdır. ${ }^{46}$ Müzik, ancak hikmet sahiplerinin ortaya koyduğu yolda icra edilirse insanın ahlâki yetkinlik kazanmasını sağlar ve meşrû kabul edilir. Ancak bunun dışında oyun-eğlence, dünya arzularına rağbet ve gururlanma için kullanılması hâlinde meşruiyetini kaybeder.

Tabiat, tümüyle bir ahenk, bir düzen ve ritimdir. Tabiattaki bu armoni, doğal olarak mûsikîyi meydana getirmiştir. Tabiat bir bütündür. İnsan da onun bir parçası olduğuna göre ondaki ahenk (armoni) insanda da vardır. Ruhî hayat, insan armonisinin en önemli faktörüdür. Psikolojik açıdan sağlıklı olduğu sürece insan, günlük yaşantısı içinde ahenkli, çevresine uyumlu ve başarılıdır. ${ }^{47}$ Pek çok faktörün tesiriyle zamanla psikolojimizde ve davranışlarımızda bozukluklar oluşabilmektedir. Mûsikî, evrendeki ve kendi içindeki uyumu hatırlatarak insanın ruh dengesini yeniden kurabilmesine yardımcı olmaktadır. Bu sebeple musiki geçmişte olduğu gibi bugün de eğitimde çok önemli bir rol oynamaktadır.

Medeniyetlerin sadece bilimsel terakkiye değil, sanata ve mûsikîye de ihtiyac1 vardır. Mûsikî sanatı ancak ictimai ve medeni hayatın bulunduğu bölgelerde gelişmektedir. ${ }^{48}$ Çocukların ve gençlerin sağlam bir ruh ve kişilik eğitimi almalarında müzik eğitimi dersinin önemli bir yeri vardır. Teorik yönü itibarı ile müzik, matematiğe dayalı bir ilim olduğundan çocuğun aklî ve fikrî melekelerini geliştirir. ${ }^{49} \mathrm{Güzel} \mathrm{sanatlar} \mathrm{eğitimi} \mathrm{araçlarının} \mathrm{en} \mathrm{güçlüsü} \mathrm{olan} \mathrm{müzik} \mathrm{vasıtasıyla} \mathrm{çocuklarda}$ sanata ilgi oluşturulur. Bu alandaki birikimleri onların kalplerini yumuşatıp ruhlarını kibarlaştırarak kötülükten uzak tutar. Müzik eğitimi onlarda aile sevgisi, vatan sevgisi ve insanlık gibi hisleri de geliştirerek çocuğu yuvasına, vatanına bağlı bireyler olmalarını sağlar. Çocukları güzelliğe karşı olduğu kadar, iyiliğe karşı da hassas hale getirerek onları düzenli ve uyumlu olmaya sevk eder. Müzik eğitimi çocuklarda güzel konuşma alışkanlığı kazandırarak okulda da disiplinli olmalarını

46 İslam tarihinde Mûsikînin eğitim ve tasavvufta icrâ edilmesi hakkında ayrıntılı bilgi için bkz: Şakir Gözütok, “İslam Eğitiminde Müzik -Başlangıcından Osmanlı Dönemine Kadar," Geçmişten Günümüze Uluslararası Dinî Mûsikî Sempozyumu Bildiriler Kitabı (2017), 389-398.

47 Ruhi Kalender, “Mûsikî ve İnsan,” Ankara Üniversitesi İlahiyat Fakültesi Dergisi, 37(1997): 264.

48 Fazlı Arslan, Medine, "Medeniyet ve Mûsikî Üstüne Bazı Düşünceler," Illahiyat Araştırmaları Dergisi, no. 3 (2015): 45.

49 Kubilay Kolukırık, Kandemir Yiğit Alkan, "İlköğretim Okullarında Verilen Müzik Eğitimi ve Müziğin Öğrenciler Üzerindeki Faydalarına İlişkin Halil Bedii Yönetken’in Düşünceleri,” Türk-İslam Medeniyeti Akademik Araştırmalar Dergisi 13, no. 7 (2012): 62, 67. Osmanlı'nın son dönemi ve günümüz Türk mûsikîsi çalışmaları hakkında ayrıntılı bilgi için bkz: Nuri Özcan, Yalçın Çetinkaya, "Mûsikî," Türkiye Diyanet Vakfi İslam Ansiklopedisi 31, (2006): 260-261. Arap İslam dünyasındaki müzik çalışmaları hakkında ayrıntılı bilgi için bkz: Wright, The Modal System of Arab and Persian Music, 20-30. 
sağlar. Onların medeni cesaretini artırarak ruhen rahatlatır. Özellikle korkak, sıkılgan çocuklar için müzik eğitimi çok önemlidir. ${ }^{50}$ Dolayısıyla çocukların ve gençlerin aklî melekelerinin güçlendirilmesinde, soyut düşünme kabiliyetlerinin geliştirilmesinde müzik eğitimi önemli bir yer teşkil etmektedir.

\section{Sonuç}

Nazarî kaideleri sistemli bir şekilde ortaya koyması hasebiyle Kindî, Arap mûsikîsi ilmî ekolünün kurucusudur. Bu ekol Fârâbî elinde gelişmiş, İbn Sînâ'da zirveye ulaşmıştır. Pythagoras etkisiyle müzikal seslerle sayılar ve gök cisimleri arasında güçlü bağlar kuran Kindî’nin bu usulünün, özellikle İhvân-1 Safâ üzerinde etkili olduğunu ifade edebiliriz. Matematik bilgisinden yoksun olanların kendi eserlerinin özüne vâkıf olamayacağını ifade eden Kindî, felsefe eğitimi almak isteyenlerin, öncelikle riyâzî ilimler içerisinde yer alan aritmetik, astronomi, mantık ve mûsikî ilimlerini öğrenmesi gerektiğini ifade eder. Platon etkisiyle, mûsikî ilminin insanın zihinsel melekelerini geliştirmede önemli rol oynadığı, bu sebeple eğitimde çok önemli bir yer teşkil ettiği görüşündedir.

İbn Sînâ sesler arasındaki uyumu gökcisimleri ile irtibatlı olarak açıklamaktan ziyâde onları sayısal bir oran olarak açıklamayı tercih etmektedir Buna karşılık İhvân- Safâ da Kindî gibi mûsikîyi feleklerle irtibatlı olarak ele almaktadır. Çalışmamızda farklı örnekler etrafında yaptığımız incelemede Kindî’nin risâleleri ve İhvân'ın mûsikî risalesi; ifadeleri, misalleri ve uslupları itibariyle oldukça benzer gözükmektedir. Hatta bazen bire bir aktarımlara rastladığımız yerler mevcuttur. $\mathrm{Bu}$ durum bizi mûsikî konusunda, İhvân-1 Safâ’nın İslam filozofları içerisinde daha ziyade Kindî’yi takip ettiği sonucuna ulaştırmıştır.

Kindî’nin düşünce sisteminde mûsikî eğitimi ahlâkî kemâle ulaşmak noktasında, bireysel olarak "ahenk" $i$, buna bağlı olarak "itidal"i yakalayabilmek için oldukça mühimdir. Zira "ilmu't-te'lif” olarak nitelenen mûsikî ilmi, evrendeki ahenk ve düzenin bir yansımasıdır. Mûsikî nağmelerini icrâ eden ya da dinleyen kişi bu ahenge tabiî olarak iştirak etmiş olmaktadır. Bu bakış açısıyla Pisagorcu mûsikî anlayışını benimseyen Kindî, mûsikînin insana etkisini, gök cisimlerinin insanın fizik ve metafizik tabiatına olan tesiri üzerinden açıklar.

Semâvî cisimlerin hareketleri insan başta olmak üzere ayaltı alemdeki tüm varlıkların oluşumuna tesir etmektedir. Ayaltı alemdeki tüm varlıklar dört unsurdan oluşmakta, basitten mürekkebe doğru bir kemâl seyri takip etmektedir. İnsan da bu oluşumunu diğer varlıklarla birlikte fiziksel açıdan gerçekleştirdiği gibi aynı

50 Kolukırık, Alkan, “İlköğretim Okullarında Verilen Müzik Eğitimi ve Müziğin Öğrenciler Üzerindeki Faydalarına İlişkin Halil Bedii Yönetken'in Düşünceleri,” 67. 
zamanda metafizik varlığ itibariyle de gerçekleştirmektedir. Mûsikî bu noktada insanın hem fiziksel hem de metafizik kemâli açısından etkili olmaktadır. Mûsikî nağmeleri, insanın bedenindeki sıvıların oranına tesir ederek mizacını etkilemekte, bu da huyları ve buna bağlı olarak ahlâkı değiştirmektedir. Bu şekilde mûsikî insanın fiziksel yapısı üzerinden ahlâki kemâle etki etmektedir. Böylelikle semâvî cisimlerin seslerine benzer şekilde belirli bir oransal uyum üzerinde bir araya gelen müzik melodileri, insanın davranışlarında olumlu tesirler bırakarak ahlâkî erdemlerin oluşmasını sağlamaktadır. Bu oransal uyumun bulunmadığı sesler de tam tersi bir etkiye sebep olmakta, erdemsizlikleri insana hatırlatmaktadır. $\mathrm{Bu}$ sebeple insanın ahlâkî yetkinliğini sağlayan müzik ilahi yasalarla da uyumlu olmalıdır. Dolayısıyla Kindî’nin mûsikînin semâvi kökenlerini arama çabası bir başka açıdan ona meşruiyet kazandırma amacı da taşımaktadır.

Müziğin insanın metafizik yapısına etkisi ise Kindî’nin tecrid ve arınma fikri çerçevesinde gerçekleşmektedir. Ayüstü âlemdeki semâvî cisimlerin hareketlerinden ortaya çıkan harmoni ayaltı âlemdeki müzik nağmeleriyle irtibatlandırılmaktadır. Bunun sonucunda bu nağmeleri dinleyen insan göksel varlıkları ve metafizik âlemleri hatırlayacak ve oraya iştiyak duyacaktır. $\mathrm{Bu}$ durumda insan maddi âlemin etkisinden uzaklaşıp metafizik âlemlere yönelecektir. Ahlâkî kemâle ulaşmanın en temel yolu olan tecrid faaliyeti bu şekilde gerçekleşmiş olmaktadır.

Günümüzde de çocukların ve gençlerin aklî melekelerinin güçlendirilmesinde müzik eğitimi oldukça etkilidir. Güzel sanatlar içerisinde önemli bir yer teşkil eden mûsikî eğitimi, soyut düşünme kabiliyetinin geliştirilmesinde de önemlidir. Aynı zamanda çocukları güzelliğe ve iyiliğe karşı hassas hale getirerek ahlâkî faziletlerin yerleştirilmesinde de mûsikî etkili bir yöntemdir. Kadîm kültürümüze ait mûsikî eserlerinin çocuklarımıza öğretilmesi, onların bu mirasa ve yaşadıkları coğrafyaya bağl11ıklarını da canlı tutacaktır. İslam filozoflarının birçoğunun mûsikî ile ilgili eserleri mevcuttur. Bunlar hakkında mûsikî nazariyâtı açısından değerli çalışmalar bulunmaktadır. Bununla birlikte meselenin ontolojik ve epistemolojik arka planı hakkında çalışmalara ihtiyaç vardır. Araştırmamızın bundan sonra bu alanda yapılacak çalışmalara mütevazı bir katkı olmasını ümit etmekteyiz.

Hakem Değerlendirmesi: Dış bağımsız.

Çıkar Çatışması: Yazar çıkar çatışması bildirmemiştir.

Finansal Destek: Yazar bu çalışma için finansal destek almadığını beyan etmiştir.

Peer-review: Externally peer-reviewed.

Conflict of Interest: The author has no conflict of interest to declare.

Grant Support: The author declared that this study has received no grant support. 


\section{Kaynakça/References}

Aristotales. Metafizik. İstanbul: Sosyal Yayınları,1996.

Aristotales. Ruh Üzerine. İstanbul: Alfa Yayınları, 2001.

Arkan, Atilla. “Kindî ve İbn Rüşd'de İnsan Tasavvuru.” İslâm Araştırmaları Dergisi 12, ( 2004): 27-54.

Arslan, Ahmet. İlkçă̆ Felsefe Tarihi. İstanbul: Bilgi Üniversitesi Yayınları, 2018, I.

Arslan, Fazlı. "Medine, Medeniyet ve Mûsikî Üstüne Bazı Düşünceler.” İlahiyat Araştırmaları Dergisi 3, (2015): 33-48.

Barker, Andrew. Pythagoras and Early Pythagoreanism. Greek Musical Writings II. Cambridge, New Yok: Cambridge University Press, 1989.

Erdemir, Ayşegül Demirhan. “Anâsır-1 Erbaa.” Türkiye Diyanet Vakfi İslam Ansiklopedisi 2, (1989): 24.

Fârâbî, Ebu Nasr Muhammed b. Muhammed b. Tarhan (ö. 330/950). İhsâü'l-ulum. tahk. Ali Bu Mülhim, Beyrut: Mektebetü'l-Hilal, 1996.

Farmer, Henry George. Tarihu'l-Musika 'l-Arabiyye. çev. H. Nassar. Kahire: 1956.

Galen, Kuva 'n-Nefs Tevâbi'li Mizâci'l-beden, tahk: Abdurrahman Bedevî, Beyrut: el-Müessesetü'lArabiyye li'd-Dirasat ve'n-Neşr, 1981.

Gözütok, Şakir. “İslam Eğitiminde Müzik -Başlangıcından Osmanlı Dönemine Kadar.” Geçmişten Günümüze Uluslararası Dinî Mûsikî Sempozyumu Bildiriler Kitab1, (2017): 389-398.

İhvân-1 Safâ. Resâ 'ilu İhvâni's-Safâ ve hullâni'l-vefâ'. tahk. Arif Tamir. Beyrut: Dâru Uveydati'dDevliyye, 1995, I.

İhvân-1 Safâ. İhvân-ı Safâ Risâleleri-Mûsikî Risâlesi, terc. Ahmet Hakk1 Turabi. ed. Abdullah Kahraman, İsmail Çalışkan. İstanbul: Ayrıntı Yayınları, 2012, I, 129-160.

Jebrini, Alaeddin. "Fârâbî-Mûsikî.” Türkiye Diyanet Vakfi İslam Ansiklopedisi 12 (1995): 162-163.

Kalender, Ruhi. "Mûsikî ve İnsan.” Ankara Üniversitesi Illahiyat Fakültesi Dergisi 37, (1997): 263-272.

Kılıç, Muhammet Fatih. "İhvân-1 Safâ'da Sanatın Ahlâki Boyutları: Müzik Üzerine Bir İnceleme.” Bilimname: Düşünce Platformu 36, no. 2 (2018), 63-90.

Kindî, Ya'kūb b. İshak. Müellefâtü'l-Kindîyyi'l-Mûsikîyye/Kitâbu'l-musavvitât. tahk. Zekeriyya Yusuf. Bağdad: 1962.

Kindî, Ya‘kūb b. İshak. Risâle fi'l-luhûn ve'n-nağam. tahk. Zekeriyya Yusuf. Bağdad: Matbaatü'şŞefik, 1965.

Kindî, Ya'kūb b. İshak. Felsefi Risâleler. neşr. Mahmut Kaya. İstanbul: Klasik Yayınları, 2014.

Kolukırık, Kubilay. Kandemir, Yiğit Alkan. "İlköğretim Okullarında Verilen Müzik Eğitimi ve Müziğin Öğrenciler Üzerindeki Faydalarına İlişkin Halil Bedii Yönetken'in Düşünceleri.” Türkİslam Medeniyeti Akademik Araştırmalar Dergisi 13, no. 7 (2012): 57-68.

Kurban, Yasin. “İnsan Tabiatı ve İslam Açısından Müzik (Müzik-Fitrat İlişkisi).” Atatürk Üniversitesi Sosyal Bilimler Enstitüsü Dergisi 32, no. 1 (2019): 21-36.

O. Wright. The Modal System of Arab and Persian Music. London: 1978.

Özcan, Nuri; Yalçın Çetinkaya. "Mûsikî.” Türkiye Diyanet Vakfi İslam Ansiklopedisi (DİA), 31, (2006): 261-263.

Özden, Ömer. "Platon ve Aritoteles'in Estetik Anlayışları.” Arayışlar-İnsan Bilimleri Araştırmaları 5-6, no. 3 (2001): 33-44. 
Platon. Devlet. terc. M. Ali Cimcöz. Sabahaddin Eyüboğlu. İstanbul: İş Bankası Yayınları, 2002.

Platon. Timaios. terc. Erol Güney, Lütfi Ay, İstanbul: 2001.

Shiloah, Amnon. Music in the World of Islam a Socio-Cultural Study. California: Wayne State University Press, 1995.

Taşkent, Ayşe. "İslam Felsefesinde Estetik: Güzelin Ontolojik, Kozmolojik, Psikolojik ve Mantıkî Bağlamda Değerlendirilmesi.” Din ve Hayat: İstanbul Müftülügü Dergisi 14, (2011): 28-32.

Hatice Toksöz, "Kindî’nin Düşünce Sisteminde Müzikal Seslerle Âlemdeki Düzen Arasındaki İlişkisi.” Diyanet İlmi Dergi 54, no. 2 (2018): 85-108.

Turabi, Ahmet Hakkı. "İlk Dönem İslâm Dünyasında Mûsikî Çalışmalarına Bakış.” Marmara Üniversitesi Illahiyat Fakültesi Dergisi 13-14-15, (1995-1997): 225-248.

Turabi, Ahmet Hakk1. “el-Kindî’nin Mûsikî Risâleleri.” Yüksek Lisans Tezi, Marmara Üniversitesi Sosyal Bilimler Enstitüsü, 1996.

Turabi, Ahmet Hakk1. "Ya'kub b. İshak el-Kindî." Türkiye Diyanet Vakfi İslam Ansiklopedisi 26, (2002): 58-59.

Turabi, Ahmet Hakk1. "EbûYa‘kūb b. İshâk el-Kindî’nin Müzik Risâlelerinde Tesbit Edilen Terimler.” Marmara Üniversitesi Illahiyat Fakültesi Dergisi 25, no. 2 (2003): 65-78.

Turabi, Ahmet Hakk1. “İbn Sînâ ve Müzik.” Uluslararası İbn Sînâ Sempozyumu Bildiriler/International Ibn Sina Symposium 2, (İstanbul): 195-216.

Türker, Ömer. "Kindî Metafiziği.” Diyanet İlmi Dergi 54, no. 2 (2018): 53-66.

Uludağ, Süleyman. İslam Açısından Mûsikî ve Sema. İstanbul: 1992.

Ülken, Hilmi Ziya. “Irak’ta Bağdat ve Kindî’nin 1000. Y1ldönümü Anma Töreni.” Ankara Üniversitesi İlahiyat Fakültesi Dergisi 10, (1962).

Y1ldı, Hakk1 Dursun. “Abbasîler.” Türkiye Diyanet Vakfi İslam Ansiklopedisi (DIA) 1, (1988): 31-48. 
